\title{
Hubungan Pemberian ASI Eksklusif dengan Tumbuhnya Gigi Sulung Pada Bayi Usia 6-36 Bulan di Posyandu Wilayah Kerja Puskesmas Tanah Garam
}

Avilia Chandrawita ${ }^{1}$, Kuswardani Susari $\mathrm{P}^{2}$, Hidayati ${ }^{1}$

Korespondensi : hidayati; hidayati@dent.unand.ac.id Telp: +6281363477441

\begin{abstract}
Background of the study: Exclusive breastfeeding is only receives breastmilk without any addition of other liquids or foods before reaching 6 months of age, where exclusive breastfeeding is the best source of nutrition and contains important nutrients that affect on the growth and the development of teeth eruption in infants. Objective: This study intended to find out the relationship of giving exclusive breastfeeding with the eruption of deciduous teeth in infants age 6-36 months at Integrated Service Post (Posyandu) in the working area of Tanah Garam Community Health Center. Method: This study used observational anaysis method with cross-sectional design. The sample taken by using Random Sampling technique in infants age 6-36 months at Integrated Service Post (Posyandu) in the working area of Tanah Garam Community Health Center as many as 95 infants. Data retrieval was carried out by interview using a questionnaire and then performed dental eruption examination. Data analysis used Chi-Square test. Result: The result of univariate analysis obtained that most of infants age6-36 months at Integrated Service Post (Posyandu) in the working area of Tanah Garam Community Health Center receive exclusive breastmilk and timing of teeth eruption on time. The result of bivariate analysis obtained $p$ value $<0,05$. Conclusion: There is significant relationship between the giving of exclusive breastfeeding with the eruption of deciduous teeth in infants age 6-36 months at Integrated Service Post (Posyandu) in the working area of Tanah Garam Community Health Center.
\end{abstract}

Keywords: Exclusive breastfeeding, Eruption of deciduous teeth

Affiliasi penulis: ${ }^{1}$ Faculty of Dentistry, Universitas Andalas, Padang, Indonesia ${ }^{2}$ Faculty of Medicine, Universitas Andalas, Padang, Indonesia

PENDAHULUAN

Pertumbuhan seorang anak diperlukan adanya patokan atau standar normal dalam penilaian klinis, agar umur fisiologis sistem jaringan bisa dibandingkan dengan umur kronologis. Salah satu proses pertumbuhan dan perkembangan pada bayi yaitu erupsi gigi yang sering dipergunakan dalam ilmu Forensik untuk memperkirakan umur anak dalam ilmu Kedokteran Gigi. Erupsi gigi juga digunakan untuk menilai maturasi gigi atau dental age secara klinis ${ }^{1}$. Erupsi gigi mendapatkan perhatian yang cukup besar bagi orang tua terutama orang tua baru, seringkali mereka berpendapat apabila gigi anaknya belum tumbuh pada saat yang seharusnya itu merupakan kesalahan pada proses perkembangan anaknya, Padahal waktu erupsi gigi pada setiap anak sangat bervariasi².

Erupsi gigi adalah pergerakan atau proses munculnya gigi ke arah rongga mulut yang dimulai sejak gigi berada di dalam tulang alveolar dan merupakan proses yang bervariasi pada setiap anak ${ }^{3}$. Erupsi gigi desidui mulai berlangsung pada anak usia 6 bulan dan diawali dengan gigi desidui insisivus sentral pada mandibulanya ${ }^{4}$. Proses pembentukan benih gigi mulai terbentuk dari 4 bulan usia kandungan, 
dan semua benih gigi desidui sudah berkembang pada usia 6 bulan pada kandungan ${ }^{5}$. Namun erupsi gigi ketika bayi lahir sangat bervariasi dan faktor yang dapat mempengaruhi erupsi gigi menurut penelitian Almonaitiene terdapat beberapa faktor yaitu faktor genetik, jenis kelamin, status gizi, sosial ekonomi dan hormonal $^{6}$, menurut penelitian Casamassimo waktu erupsi gigi desidui diawali dengan erupsinya gigi insisivus sentral mandibula pada usia 6 bulan dan erupsi gigi desidui umumnya lengkap saat anak berusia 3 tahun 4 .

Erupsi gigi yang terjadi di dalam mulut mengalami urutan waktu erupsi yang berbeda pada setiap jenis gigi, diawali dengan fase gigi sulung hingga digantikan dengan fase gigi permanen, sehingga menyebabkan adanya variasi waktu dan urutan munculnya kedua jenis gigi tersebut ${ }^{8}$. Pertumbuhan dan perkembangan gigi dan mulut dipengaruhi zat gizi, baik secara sistemik maupun secara lokal. Pada tahap dini pertumbuhan gigi dipengaruhi oleh sejumlah faktor yaitu $\mathrm{Ca}, \mathrm{P}, \mathrm{F}$, dan vitamin dalam diet $^{9}$.Pada penelitian Boejamin tahun 1999 menyebutkan waktu erupsi gigi sulung pada bayi yang mendapatkan ASI ekslusif lebih cepat jika dibandingkan dengan bayi yang mendapatkan PASI (Pengganti Air Susu lbu) ${ }^{10}$. Penelitian lain menyebutkan terdapat jumlah gigi insisif sulung yang berbeda pada bayi usia 12 bulan yang mendapatkan ASI ekslusif dan PASI ${ }^{11}$.

ASI ekslusif menurut WHO (World Health Organization) adalah pemberian ASI saja tanpa tambahan cairan lain baik susu formula, air putih, air jeruk, ataupun makanan tambahan lain, sebelum mencapai usia 6 bulan. Sistem pencernaan bayi belum mampu berfungsi dengan sempurna sehingga ia belum mampu mencerna makanan selain ASI ${ }^{12}$. Pada tahun 2000 pemerintah Indonesia menetapkan target ibu menyusui bayinya secara ekslusif sekurangnya 80\% namun semakin bertambahnya usia anak semakin berkurang presentase pemberian ASI kepada anak, Pada anak usia 0 bulan presentase anak yang mendapatkan ASI ekslusif sebesar 39,8\% namun pada anak usia 5 bulan presentase anak yang mendapatkan ASI menurun menjadi $15,3 \%^{13}$. Sedangkan di Sumatera Barat bayi yang mendapatkan ASI ekslusif sebanyak $68,9 \%{ }^{14}$. Air susu ibu (ASI) merupakan makanan bagi anak semasa bayi yang mengandung nutrisi optimal, baik kualitas maupun kuantitasnya. Pemberian ASI merupakan metode pemberian makan bayi yang terbaik, karena ASI mengandung semua zat gizi dan cairan yang dibutuhkan untuk memenuhi seluruh kebutuhan gizi pada bayi usia 6 bulan pertama ${ }^{15}$.

Menurut data BPS (Badan Pusat Statistik) tahun 2010 untuk kota Solok populasi anak usia balita yang paling banyak terdapat pada Puskesmas Tanah Garam. Puskesmas Tanah Garam memiliki empat Pustu dan 23 Posyandu. Menurut info Publik Solok (IPS) Posyandu Kota Solok merupakan Posyandu yang aktif dengan bukti mendapatkan penghargaan tingkat nasional yaitu penghargaan Pakarti Madya III pada tahun 2017. Berdasarkan uraian-uraian di atas peneliti merasa tertarik untuk meneliti permasalahan yaitu hubungan pemberian ASI ekslusif dimana ASI ekslusif merupakan sumber gizi terbaik bagi bayi dengan erupsi gigi desidui pada anak usia 6-36 bulan di Posyandu wilayah kerja Puskesmas Tanah Garam.

METODE

Jenis penelitian yang digunakan adalah penelitian analitik observasional dengan pendekatan Cross Sectional Study. Sampel dalam penelitian ini diambil dengan metode simple random sampling. 
Jumlah sampel dalam penelitian ini adalah 95 orang anak yang berusia 6-36 bulan di Posyandu wilayah kerja Puskesmas Tanah Garam Kota Solok. Pengolahan data dilakukan menggunakan uji statistik menggunakan uji Chi Square dengan bantuan aplikasi komputer.

Setelah melakukan screening didapat responden yang memenuhi kriteria inklusi. Responden yang memenuhi kriteria dan bersedia dilakukan penelitian diberikan informed consent untuk ditandatangani oleh orang tua anak. Selanjutnya pemeriksaan erupsi gigi menggunakan kaca mulut. Penelitian dilanjutkan dengan melakukan wawancara mengenai pola pemberian ASI anak menggunakan kuisioner yang didampingi oleh peneliti kepada responden.

\section{HASIL DAN PEMBAHASAN}

Posyandu wilayah kerja Puskesmas Tanah Garam Kota Solok merupakan tempat pengambilan data responden, besar sampel dalam penelitian ini adalah sebanyak 95 responden yang berusia 6-36 bulan. Reponden penelitian berdasarkan jenis kelamin di Posyandu wilayah kerja Puskesmas Tanah Garam Kota Solok memiliki proporsi responden wanita lebih banyak dibandingkan dengan laki-laki. Responden wanita yaitu sebanyak 53 orang $(55,8 \%)$ dari responden yang berjenis kelamin Laki-laki sebanyak 42 orang $(44,2 \%)$.

Pada penelitian ini, peneliti membagi pola pemberian ASI menjadi dua yaitu pemberian ASI secara ekslusif dan pemberian ASI non ekslusif. Hasil penelitian menunjukan sebagian besar anak-anak di Posyandu wilayah kerja Puskesmas Tanah Garam lebih banyak diberi ASI secara esklusif yaitu sebesar 69,5\% (66 orang) dibandingkan dengan anak yang diberi ASI non ekslusif yaitu sebesar 30,5\% (29 orang). Hal ini sejalan dengan ketetapan yang dibuat pemerintah Indonesia Pada tahun 2000 pemerintah Indonesia menetapkan target ibu menyusui bayinya secara ekslusif sekurangnya $80 \%$. Walaupun demikian target pemberian ASI ekslusif di puskesmas Tanah garam belum tercapai. Selain itu pada tahun 2002 WHO merekomendasikan seorang ibu wajib memberikan ASI maksimum 2 tahun, 6 bulan berupa ASI ekslusif, dan ASI yang didampingi dengan makanan tambahan sampai umur 2 tahun. Namun pada wilayah negara-negara berkembang prevalensi pemberian ASI ekslusif masih terlalu rendah ${ }^{16}$.

Pemberian ASI eksklusif untuk enam bulan pertama setelah kelahiran berkontribusi secara signifikan terhadap pembangunan kekebalan tubuh bayi yang kuat dan optimal, sehingga dapat mencegah infeksi yang masuk pada tubuh bayi dan mencegah terjadinya kematian bayi ${ }^{16}$. Bayi yang mendapatkan ASI ekslusif umumnya akan mengalami pertumbuhan yang sangat pesat pada usia 2-3 bulan karena ASI ekslusif mendukung pertumbuhan bayi selama 6 bulan pertama sehingga status gizi mencapai normal ${ }^{17}$. Selain itu dengan memberikan ASI secara ekslusif kepada anak, akan menjamin tercapainya pengembangan potensi kecerdasan anak secara optimal ${ }^{18}$.

Hasil penelitian ini menunjukkan bahwa persentase responden yang diberi ASI ekslusif lebih banyak terjadi pada anak perempuan yaitu $57,6 \%$. Hal ini sejalan dengan data BPS sumatera barat pada tahun 2017 yang menyebutkan jumlah penduduk wanita lebih banyak dibandingkan dengan penduduk laki-laki ${ }^{19}$.

Erupsi gigi merupakan gerak normal gigi ke arah rongga mulut dari posisi pertumbuhannya dalam tulang alveolar ${ }^{9}$. Selanjutnya menurut Kurniasih erupsi gigi merupakan kombinasi pergerakan seluruh bagian gigi baik sebelum dan sesudah mahkota muncul ke dalam rongga mulut ${ }^{2}$. Penilaian Erupsi gigi 
desidui berdasarkan penelitian yang dilakukan di Posyandu Wilayah Kerja Puskesmas Tanah Garam bertujuan untuk mengetahui hubungan pemberian ASI ekslusif dengan erupsi gigi desidui. Berdasarkan hasil penelitian diketahui bahwa erupsi gigi desidui yang tepat waktu lebih banyak dibandingkan dengan erupsi gigi desidui yang terlambat yaitu sebesar $67,4 \%$ (64 orang) yang erupsi gigi desidui tepat waktu dan yang mengalami erupsi gigi desidui yang terlambat yaitu sebesar $32,6 \%$ (31 orang). Hal tersebut disebabkan karena asupan gizi yang baik dari ASI dapat memberi banyak pengaruh bagi erupsi gigi desidui1" ${ }^{11}$. Dengan pemberian ASI secara ekslusif asupan gizi pada tubuh anak sepenuhnya hanya di dapatkan dari ASI dan anak tidak akan kehilangan kesempatan sedikitpun asupan gizi yang terkandung pada ASI dimana ASI memegang peranan penting dalam menjaga kesehatan dan kelangsungan hidup bayi ${ }^{20}$ selain itu menurut penelitian yang dilakukan Folayan dkk di Nigeria pemberian ASI eksklusif dalam 6 bulan pertama kehidupan anak terbukti memiliki banyak keuntungan termasuk menurunkan angka kematian bayi'12.

Faktor yang dapat mempengaruhi erupsi gigi desidui yaitu gizi, status gizi yang baik dapat menunjang pertumbuhan dan keseimbangan lingkungan mulut yang dihubungkan dengan kesehatan gigi, hal ini sejalan dengan penelitian yang dilakukan oleh Lantu dkk yaitu adanya hubungan status gizi dengan erupsi gigi ${ }^{3}$. Gizi pada anak dapat diperoleh dengan mengonsumsi ASI secara ekslusif karena ASI merupakan nutrisi pertama yang diterima oleh bayi saat baru lahir dan di dalam ASI terdapat kandungan gizi yang sangat tinggi, hal ini sejalan dengan penelitian yang dilakukan Nilakesuma tahun 2015 yang menyebutkan pada ASI terdapat kandungan gizi yang cukup tinggi ${ }^{22}$.

Tabel 1. Hubungan Pemberian ASI Ekslusif dengan Erupsi Gigi Desidui

\begin{tabular}{|c|c|c|c|c|c|c|}
\hline \multirow{3}{*}{ Pola Pemberian ASI } & \multicolumn{4}{|c|}{ Kategori Erupsi Gigi } & \multirow{3}{*}{ Total } & \multirow{3}{*}{$\begin{array}{c}\text { Nilai } \\
p\end{array}$} \\
\hline & \multicolumn{2}{|c|}{ Tepat waktu } & \multicolumn{2}{|c|}{ Terlambat } & & \\
\hline & $\mathbf{n}$ & $\%$ & $\mathrm{n}$ & $\%$ & & \\
\hline ASI Ekslusif & 57 & $86,4 \%$ & 9 & $13,6 \%$ & 66 & \\
\hline ASI Non Ekslusif & 7 & $24,1 \%$ & 22 & $75,9 \%$ & 29 & 0,001 \\
\hline Total & 64 & $66,7 \%$ & 31 & $32,6 \%$ & 95 & \\
\hline
\end{tabular}

Berdasarkan Tabel 1, dapat dilihat bahwa dengan pemberian ASI Ekslusif erupsi gigi desidui lebih tepat waktu dibandingkan dengan anak yang tidak mendapat ASI secara ekslusif, Anak yang tidak mengonsumsi ASI eksusif cenderung terlambat erupsi giginya. Setelah dilakukan uji statistik didapatkan nilai $p=0,001 \quad(P<0,05)$ ini berarti terdapat hubungan yang bermakna antara pemberian ASI ekslusif dengan erupsi gigi desidui pada anak usia 6-36 bulan di Posyandu Wilayah Kerja Puskesmas Tanah Garam. Selain itu dari hasil penelitian didapatkan bahwa responden yang diberi ASI secara ekslusif, ratarata erupsi gigi desiduinya tepat waktu sedangkan responden yang diberi ASI non ekslusif, rata-rata erupsi gigi desiduinya terlambat. Hal ini disebabkan oleh susu formula yang tidak dapat mengoptimalkan pertumbuhan bayi akibat proses pencernaan dengan konsentrasi tertentu yang tidak sesuai dengan daya serap saluran cerna bayi, yang menyebabkan bayi mendapatkan gizi yang kurang sehingga pertumbuhan gigi menjadi terlambat. Hal ini membuktikan bahwa adanya hubungan pemberian ASI ekslusif terhadap 
erupsi gigi desidui pada anak usia 6-36 bulan Dari hasil penelitian didapatkan anak yang diberikan ASI ekslusif erupsi giginya tepat waktu dibandingkan anak yang tidak mendapatkan ASI ekslusif. Hal ini sejalan dengan hasil penelitian yang dilakukan oleh Windiyati (2012) dalam penelitiannya, yaitu bayi yang mendapat ASI secara ekslusif akan mengalami lebih cepat dalam tumbuh gigi dibandingkan dengan bayi yang mendapatkan susu formula ${ }^{23}$.

Erupsi gigi bayi yang mendapatkan ASI secara ekslusif berdasarkan hasil penelitian yang dilakukan hampir seluruhnya tepat waktu dalam pertumbuhan giginya yaitu sebanyak 57 responden $(86,4 \%)$, dan yang erupsi giginya tidak tepat waktu sebanyak 9 orang (13,6\%). Bayi yang mendapat ASI Non ekslusif hampir seluruhnya erupsi giginya terlambat yaitu sebanyak $22(75,9 \%)$ responden dan yang erupsi giginya tepat waktu sebanyak 7 responden (24,1\%). Anak yang mendapatkan ASI ekslusif namun erupsi giginya terlambat dan anak yang mengkonsumsi ASI non ekslusif namun erupsi giginya tepat waktu dikarenakan tidak hanya ASI ekslusif saja yang merupakan faktor yang mempengaruhi erupsi gigi anak namun ada beberapa faktor lain yang dapat mempengaruhi erupsi gigi pada anak seperti faktor genetik, kelahiran prematur, status gizi, faktor RAS dan kondisi sitemik dari anak tersebut.

\section{SIMPULAN}

Sebagian besar anak-anak usia 6-36 bulan diberi ASI ekslusi dan terdapat terdapat hubungan yang bermakna antara pemberian ASI ekslusif dengan erupsi gigi desidui pada anak usia 6-36 bulan di Posyandu wilayah kerja Puskesms Tanah Garam Kota Solok dengan nilai $p=0.001$.

\section{KEPUSTAKAAN}

1. Kuswandari, Sri. Maturasi dan Erupsi Gigi Permanen pada Anak Periode Gigi Pergantian. Dental Journal. 2014: vol. 47 (2).

2. Kurniasih, Indri. Permasalahan-permasalahan yang Menyertai Erupsi Gigi. Mutiara Medika, 2008; 8(1): 52-59.

3. Lantu, Virginia A.R., Shirley E.S. Kawengian dan Vonny N.S. Wowor. Hubungan Status Gizi dengan Erupsi Gigi Permanen Siswa SD Negeri 70 Manado. Jurnal e-GiGi, 2015: vol. 3 (1).

4. Noorharsanti, Aprilia Tri dan Maria Mexitalia, Hubungan Jumlah Gigi Susu dengan Pola Makan Anak Usia 9-24 Bulan. Jurnal Media Medika Muda. 2014.

5. Itjiningsih, W.H., Anatomi Gigi, Jakarta: EGC Penerbit Buku Kedokteran. 2002.

6. Almonaitiene, R, I Balciuniene, dan J. Tutkuviene. Factors Influencing Permanent Teeth Eruption. Stomatologija, Baltic Dental and Maxillofacial Journal. 2010: vol. 12(3).

7. Casamassimo, et al, Missense Pathogenic variants in KIF4A Affect Dental Morphogenesis Resulting in X-linked Taurodontism, Microdontia and Dens-Invaginatus, 2019. Front. Genet., https://doi.org/10.3389/fgene.2019.00800.

8. Oktaviana, Ilza Rinaldy. Derajat Erupsi Gigi Anak Usia 7 Tahun pada Etnis Arab di SD Al Irsyad Surabaya. Jurnal Departemen Antropologi Fakultas IImu Sosial dan IImu Politik Universitas Airlangga. 2016: vol. 5 (3). 
Fakultas Kedokteran Gigi Universitas Andalas

Jalan Perintis Kemerdekaan No. 77 Padang, Sumatera Barat

Web: adj.fkg.unand.ac.id Email: adj@dent.unand.ac.id

9. Sukma, Normayanti dan Ana Medawati. Hubungan antara Status Gizi dengan Status Erupsi Gigi Molar Tiga. IDJ. 2012: vol. 1 (1).

10. Prayogo, Dedy Setyo. Pengaruh Pemberian ASI Ekslusif terhadap WaktuErupsi Gigi Sulung pada Bayi Di Wilayah Kerja Puskesmas Nogosari Kabupaten Jember. Karya Tulis IImiah. Fakultas Kedokteran Gigi Universitas Jember. 2002.

11. Setiyowati, Lili. Perbedaan Jumlah Gigi Insisif Sulung yang Telah Erupsi antara Pemberian Air Susu Ibu (ASI) Ekslusif dan Pengganti Air Susu Ibu (PASI) (Studi pada Bayi Usia 12 Bulan Di Wilayah Kerja Puskesmas Sumbersari Kabupaten Jember). Karya Tulis IImiah. Fakultas Kedokteran Gigi Universitas Jember. 2006.

12. Endarwati, Dewi dan Tri Suwarni. Hubungan Pemberian ASI ekslusif dengan berat badan bayi Usia 6 Bulan di Posyandu Desa Mulur, Bendosari, Sukoharjo. Indonesian Journal on Medical Science. 2018; vol. 5(1).

13. RISKESDAS. Riset Kesehatan Dasar Badan Penelitian Dan Pengembangan Kesehatan Kementrian Kesehatan RI Tahun 2010. 2010.

14. RISKESDAS. Riset Kesehatan Dasar Badan Penelitian Dan Pengembangan Kesehatan Kementrian Kesehatan RI Tahun 2013. 2013.

15. Sulustiyowati, Tutuk dan Pulung Siswantara. Perilaku Ibu Bekerja Dalam Memberikan ASI Eksklusif di Kelurahan Japanan Wilayah Kerja Puskesmas Kemlagi- Mojokerto. Jurnal Promkes. 2014: vol. 2(1).

16. Ketbi, et al., Knowladge, attitude, and practice of breastfeeding, among women visiting primary healthcare clinics on the island of Abu Dhabi, United Arab Emirates. International Breastfeeding Journal. 2018; 13: 26.

17. Fitri, Dian Insana, Eva Chundrayetti dan Rima Semiarty. Hubungan Pemberian ASI dengan Tumbuh Kembang Bayi Umur 6 Bulan di Puskesmas Nanggalo. Jurnal Kesehatan Andalas, 2014: vol. 3(2).

18. Saputra, Andrian Reza. Peran Pemberian ASI Ekslusif terhadap Status Gizi dan Tumbuh Kembang pada Anak Usia Dini. J Agromed Unila. 2016: vol. 3(1).

19. BPS. Badan Pusat Statistik Sumatera Barat Tahun 2017. 2017.

20. Helda, Kebijakan Peningkatan Pemberian ASI Ekslusif. Jurnal Kesehatan Masyarakat Nasional. 2009: vol. 3(5).

21. Folayan, Oziegbe EO dan Esan AO. Breastfeeding, timing and number of erupted teeth in first twelve months of life in Nigerian Children. Eur Arch Peadiatr Dent, 2010; 11(6): 279-82.

22. Nilakesuma, Aisyah, Yusri Dianne Jurnalis dan Selfi Renita Rusjdi. Hubungan Status Gizi Bayi dengan Pemberian ASI Ekslusif, Tingkat Pendidikan Ibu dan Status Ekonomi Keluarga di Wilayah Kerja Puskesmas Padang Pasir. Jurnal Kesehatan Andalas. 2015: vol. 4(1).

23. Windiyati dan S. Arismawati. Evaluasi Antara Pemberian ASI secara Ekslusif dan Pemberian Susu Formula Pada Bayi 0-6 Bulan dengan Percepatan Pertumbuhan Gigi Pertama kali Pada Bayi Usia 612 Bulan di UPTD Puskesmas Kecamatan Pontianak tahun 2017. Jurnal Kebidanan. 2017: vol. 7(2). 